УДК 378.147:[37.091.3+811]

Рудніцька Катерина Валеріївна

кандидат педагогічних наук, доцент кафедри іноземних мов

Хмельницький національний університет, м. Хмельницький, Україна

ORCID ID 0000-0002-9644-8226

karudik29@gmail.com

Дроздова Вероніка В'ячеславівна

кандидат педагогічних наук, доцент, доцент кафедри іноземних мов

Хмельницький національний університет, м. Хмельницький, Україна

ORCID ID 0000-0002-2367-8784

ehorova@ukr.net

\title{
ОРГАНІЗАЦІЯ САМОСТІЙНОЇ РОБОТИ СТУДЕНТІВ ЗАСОБАМИ МООDLЕ В ПРОЦЕСІ НАВЧАННЯ ІНОЗЕМНОЇ МОВИ
}

\begin{abstract}
Анотація. Автори проаналізували проблему організації самостійної роботи студентів у вищій школі на основі вивчення педагогічної, психологічної та методичної літератури, програмнометодичної документації ВН3, досвіду практичної роботи. У зв’язку 3 нормативним збільшенням погодинного навантаження на самостійну роботу студентів виникла необхідність використання Moodle. Виявлено, що організація самостійної роботи студентів засобами Мoodle в процесі вивчення іноземної мови недостатньо досліджена. Для розв'язання зазначеної проблеми розроблено нову робочу програму 3 вивчення іноземної мови студентами економічних спеціальностей першого року навчання й авторський спецкурс «Професійна мова економіста». Визначено основні переваги спецкурсу для організації самостійної роботи студентів, моніторингу й аналізу активності студентів у процесі вивчення іноземної мови. Експериментально перевірено і доведено ефективність організації самостійної роботи студентів засобами Moodle в процесі вивчення іноземної мови.
\end{abstract}

Ключові слова: самоосвіта; самостійна робота студентів; Moodle; іноземна мова; навчальнопізнавальна діяльність; авторський спецкурс; контроль.

\section{1. ВСТУП}

Постановка проблеми. Сучасні соціально-економічні умови, інтеграція України у європейський і світовий простір, динамічні зміни на ринку праці, приєднання України до Болонського процесу висувають нові вимоги до підготовки студентів у вищих навчальних закладах. У зв'язку з цим вища освіта України зараз знаходиться в активній фазі реформування, яке має привести систему вітчизняної вищої школи у відповідність із загальносвітовими і європейськими стандартами. Першочергового значення набуває оновлення й реструктурування навчальних планів, робочих програм і змісту навчальних дисциплін, зокрема іноземної мови, про що свідчать новий Закони України «Про вищу освіту» (2014р.) [1] та інші нормативні документи. Низка нововведень стосується також перерозподілу навчального навантаження викладачів і студентів, що приводить до скорочення аудиторних годин і збільшення погодинного навантаження на самостійну роботу студентів (СРС).

Організація самостійної роботи як системи повинна забезпечувати оптимальні умови для навчально-пізнавальної діяльності студента. Самостійна робота студента - це різновид 
пізнавальної діяльності, який керується і контролюється викладачем і спрямований на набуття і закріплення знань і вмінь; формування самостійної особистості [2].

Цінність самостійної роботи полягає в іiі спроможності формувати виняткові риси i властивості кваліфікованого фахівця, пізнавальну активність і самостійність, здатність до самоосвіти й саморозвитку. Однак без застосування нових підходів, додаткових організаційних заходів 3 моніторингу, самостійна робота студента перетвориться на рутинне виконання завдань без чіткої мотивації.

У Хмельницькому національному університеті ефективність організації СРС забезпечується розробленими методичними матеріалами і рекомендаціями, проведенням індивідуальних і тематичних консультацій, застосуванням різних форм контролю, доступністю і вмінням працювати 3 комп'ютером, як студентів, так і викладачів, та використовувати Moodle.

Moodle (Modular Object-Oriented Dynamic Learning Environment) - це модульне об'єктно-орієнтоване динамічне навчальне середовище, яке називають також системою управління навчанням (LMS), системою управління курсами (CMS), віртуальним навчальним середовищем (VLE) або просто платформою для навчання, яка надає викладачам, учням та адміністраторам дуже розвинутий набір інструментів для комп'ютеризованого навчання, у тому числі дистанційного. Moodle можна використовувати в навчанні школярів, студентів, у підвищенні кваліфікації, бізнеснавчанні, як у комп'ютерних класах навчального закладу, так і для самостійної роботи вдома [3].

Аналіз останніх досліджень і публікацій. Проблема організації самостійної роботи студентів на теоретико-методологічному рівні досліджена в працях багатьох науковців, а саме: А. Алексюка, С. Архангельського, Ю. Бабанського, Л. Журавської, А. Леонтьєва, С. Рубінштейна та ін.; теоретичні й методичні засади дистанційного навчання у вищій школі вивчали Ю. Богачков, Н. Болюбаш, О. Веренич, Т. Койчева, К. Колос, В. Кухаренко Л. Романишина та ін.; використання інформаційних технологій у викладанні й вивченні іноземної мови висвітлено у працях вітчизняних дослідників В. Краснопольського, Л. Морської, П. Сердюкова та зарубіжних - Г. Козлакової, І. Козубовської, К. Крамш, I. Морєва та ін.

Водночас аналіз науково-педагогічної літератури і практичний досвід засвідчують, що проблема організації самостійної роботи студентів засобами Moodle в процесі вивчення іноземної мови недостатньо досліджена.

Мета статті полягає в експериментальній перевірці ефективності організації самостійної роботи студентів засобами Moodle в процесі вивчення іноземної мови.

Відповідно до мети визначено такі завдання дослідження.

1. 3'ясувати стан дослідженості проблеми організації самостійної роботи студентів засобами Moodle в процесі вивчення іноземної мови.

2. Розробити робочу програму й авторський спецкурс «Професійна мова економіста» засобами Moodle.

3. Експериментально перевірити ефективність організації самостійної роботи студентів засобами Moodle в процесі вивчення іноземної мови після впровадження авторського спецкурсу «Професійна мова економіста». 


\section{2. МЕТОДИ ДОСЛІДЖЕННЯ}

Для розв'язання поставлених завдань було використано такий комплекс методів дослідження: теоретичні - аналіз наукових джерел, педагогічної, психологічної літератури й навчально-методичних матеріалів, порівняння; емпіричних - анкетування, бесіди, тестування, узагальнення педагогічного досвіду; педагогічний експеримент 3 метою перевірки ефективності організації самостійної роботи студентів засобами Moodle в процесі вивчення іноземної мови; аналіз продуктів діяльності (аналіз робочих програм кафедр факультету економіки та управління ХНУ) використано з метою виявлення змін щодо розподілу навантаження на самостійну роботу студентів; математичноі статистики - для оброблення отриманих результатів.

Дослідно-експериментальна робота проводилася на базі Хмельницького національного університету впродовж 2015-2017 рр. й охоплювала три взаємопов' язаних етапи. До експерименту було залучено 106 студентів (1 курсу) економічних спеціальностей, з яких були сформовані експериментальна (52 студенти) та контрольна (54 студенти ) групи. Проведено зріз знань володіння іноземною мовою студентами обох груп методом тестування (стартовий контроль). Оброблення результатів здійснювалося за п’ятибальною шкалою оцінювання СКТС, яку використовує ХНУ для оцінювання якості студентських досягнень (табл. 1).

Табличя 1

Співвідношення вітчизняної шкали оцінювання і шкали оцінювання СКТС

\begin{tabular}{|c|c|c|c|}
\hline Оцінка & Інституційна & & Вітчизняна оцінка, критерії \\
\hline A & $4,75-5,00$ & 5 & $\begin{array}{l}\text { Bidмінно - глибоке і повне опанування навчального } \\
\text { матеріалу і виявлення відповідних умінь та навиків }\end{array}$ \\
\hline B & $4,25-4,74$ & 4 & $\begin{array}{l}\text { Добре - повне знання навчального матеріалу } 3 \\
\text { кількома незначними помилками }\end{array}$ \\
\hline $\mathrm{C}$ & $3,75-4,24$ & 4 & $\begin{array}{l}\text { Добре - в загальному правильна відповідь } 3 \text { двома- } \\
\text { трьома суттєвими помилками }\end{array}$ \\
\hline $\mathrm{D}$ & $3,25-3,74$ & 3 & $\begin{array}{l}\text { Задовільно - неповне опанування програмного } \\
\text { матеріалу, але достатнє для практичної діяльності за } \\
\text { професією }\end{array}$ \\
\hline $\mathrm{E}$ & $3,00-3,24$ & 3 & $\begin{array}{llccc}\text { Задовільно } & - & \text { неповне } & \text { опанування } & \text { програмного } \\
\text { матеріалу, що задовольняє } & \text { мінімальні } \\
\text { оцінювання }\end{array}$ \\
\hline FX & $2,00-2,99$ & 2 & $\begin{array}{l}\text { Незадовільно - безсистемність одержаних знань i } \\
\text { неможливість продовжити навчання без додаткових } \\
\text { знань } 3 \text { дисципліни }\end{array}$ \\
\hline $\mathrm{F}$ & $0,00-1,99$ & 2 & $\begin{array}{l}\text { Незадовільно - необхідна серйозна подальша робота і } \\
\text { повторне вивчення дисципліни }\end{array}$ \\
\hline
\end{tabular}

Згідно із загальноєвропейськими рекомендаціями з мовної освіти існує шість рівнів володіння мовою, які були розроблені Асоціацією Мовних Експертів ALTE (The Association of Language Testers in Europe): інтродуктивний (Breakthrough або A1), середній (Waystage або A2), рубіжний (Threshold або B1), просунутий (Vantage або В2), автономний (Effective Operational Proficiency або C1) і компетентний (Mastery або C2). Проаналізувавши результати тестування студентів, нами встановлена відповідність 
зазначених рівнів шкалі оцінювання ЄКТС, а саме: інтродуктивний (А1) - 3,25-3,74; середній (А2) - 3,75-4,24; рубіжний (B1) - 4,25-4,74, просунутий (B2) - 4,75-5,00.

\section{3. РЕЗУЛЬТАТИ ДОСЛІДЖЕННЯ}

На констатувальному етапі (2015-2016 pp.) експерименту здійснено аналіз проблеми шляхом вивчення педагогічної, психологічної та методичної літератури, програмно-методичної документації ВН3, досвіду практичної роботи. Вивчення робочих програм навчальної дисципліни «Іноземна мова» для студентів першого курсу економічних спеціальностей ХНУ виявило тенденцію збільшення навантаження на СРС, а саме: 56 годин (2013-2014 н. p.), 80 год. (2014-2015 н. р.), 110 год. (2015-2016 н. р.).

Зазначений аналіз документації ХНУ допоміг зробити висновки щодо нагальності оновлення змісту й пошуку нових ефективних форм і засобів організації СРС для вивчення іноземної мови. Це дало підстави для розроблення нової робочої програми з вивчення іноземної мови студентами економічних спеціальностей першого року навчання й авторського спецкурсу «Професійна мова економіста». Розроблений нами спецкурс охоплює такі напрями підготовки: «Фінанси і кредит», «Економічна кібернетика», «Економіка підприємства», «Облік і аудит» та містить такі структурні компоненти (рис. 1):

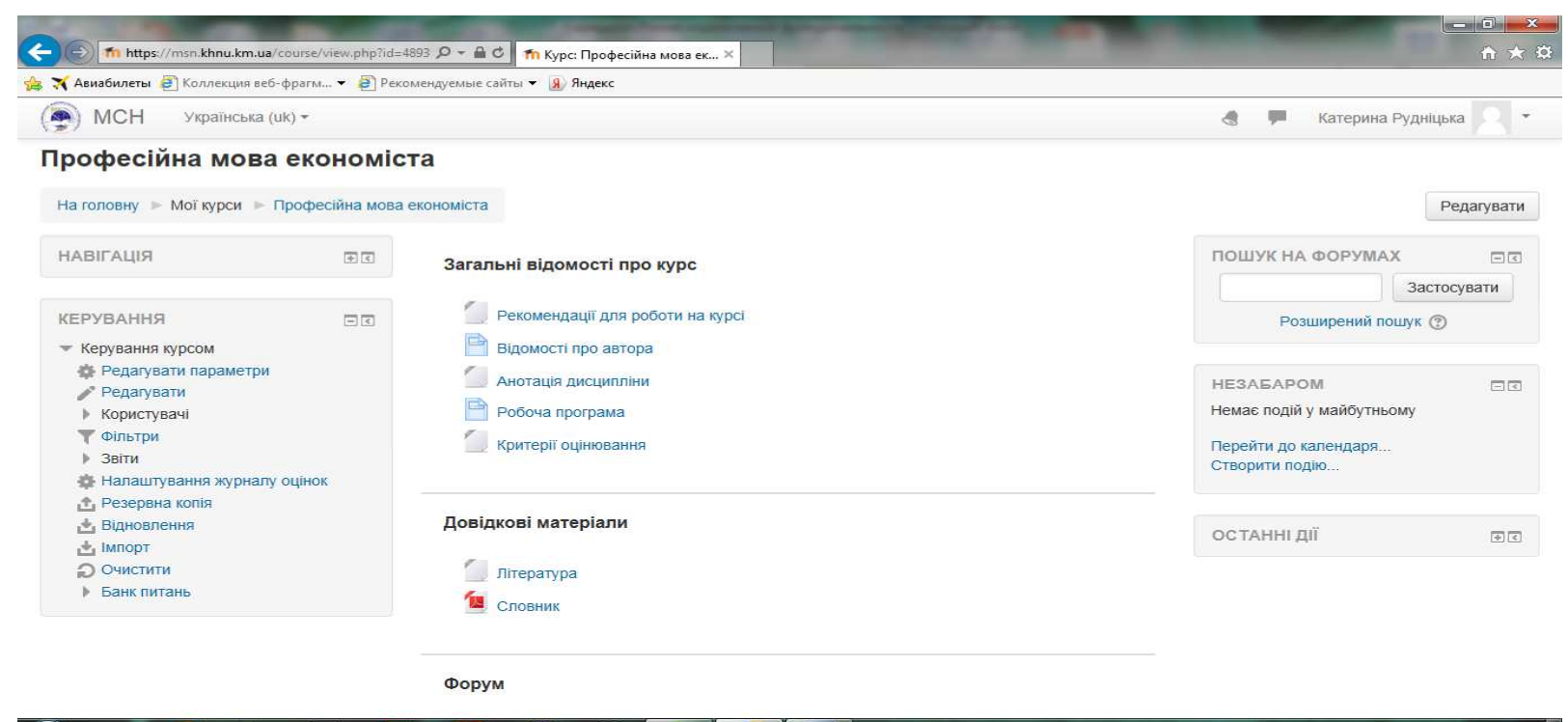

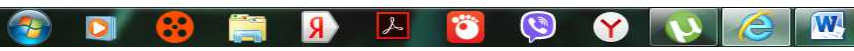

Рис. 1. Скріншот сторінки спецкурсу «Професійна мова економіста»

1. Загальні відомості про спецкурс: рекомендації для роботи на спецкурсі, відомості про автора, анотація дисципліни, робоча програма, критерії оцінювання.

2. Довідкові матеріали.

3. Блок для встановлення контакту з користувачами - форум.

4. Навчальний курс, структурований за модулями.

5. Блок завдань для самостійної роботи студента.

6. Блок творчих завдань.

7. Блок моніторингу та контролю. 
Авторський спецкурс «Професійна мова економіста» розрахований на 180 годин (5 кредитів) і складається з практичної частини (аудиторна робота (практичні заняття) - 70 годин) і самостійної роботи (110 годин). Мета спецкурсу полягає у формуванні, розвитку й удосконаленні навичок самостійної роботи 3 вивчення іноземної мови в майбутніх фахівців економічного профілю на професійному, побутовому та культурологічному рівні; комунікативних навичок у сферах професійного і ситуативного спілкування в усній i письмовій формах.

На основі результатів анкетування студентів і власному педагогічному досвіду, ми дійшли висновку, що на аудиторну роботу доцільно виносити вивчення тем професійного змісту, оскільки вони передбачають опрацювання фахових текстів, фахової лексики, які викликають певні труднощі в засвоєнні. У цьому процесі для їх подолання значну роль виконує викладач. Для самостійної роботи раціонально пропонувати студентам теми більш життєвого, культурологічного змісту, що не складають певних труднощів для їх опанування, сприяють розвитку пізнавального інтересу, розширенню світогляду студентів, розвитку професійної й особистісної культури. Переконані, що не можна формувати життєві цінності студента в процесі навчальної діяльності лише шляхом виконання завдань, поставлених викладачем. Вони формуються студентом як у контексті організованого педагогічного процесу, так і поза його межами в режимі самостійної роботи. Саме тому робота має бути організована так, щоб проектувати подальший самостійний пошук над проблемами, які мають для студента не лише професійний, а й особистісний життєвий смисл.

Беручи до уваги зазначене вище, структуру спецкурсу сформовано на засадах модульного підходу, вона складається з трьох змістових модулів і передбачає вивчення таких тем: Module 1 - Language for professional development of economist: «Banking», «Money and its functions», «Investment», «Insurance», «Marketing», «Auditing»; Module 2 Language portfolio of economist: «Presentation», «Business meeting», «Negotiations», «Business phone calls»; Module 3 - Scientific language of economist: «Business letter», «Email», «Summary», «Report». (рис. 2).

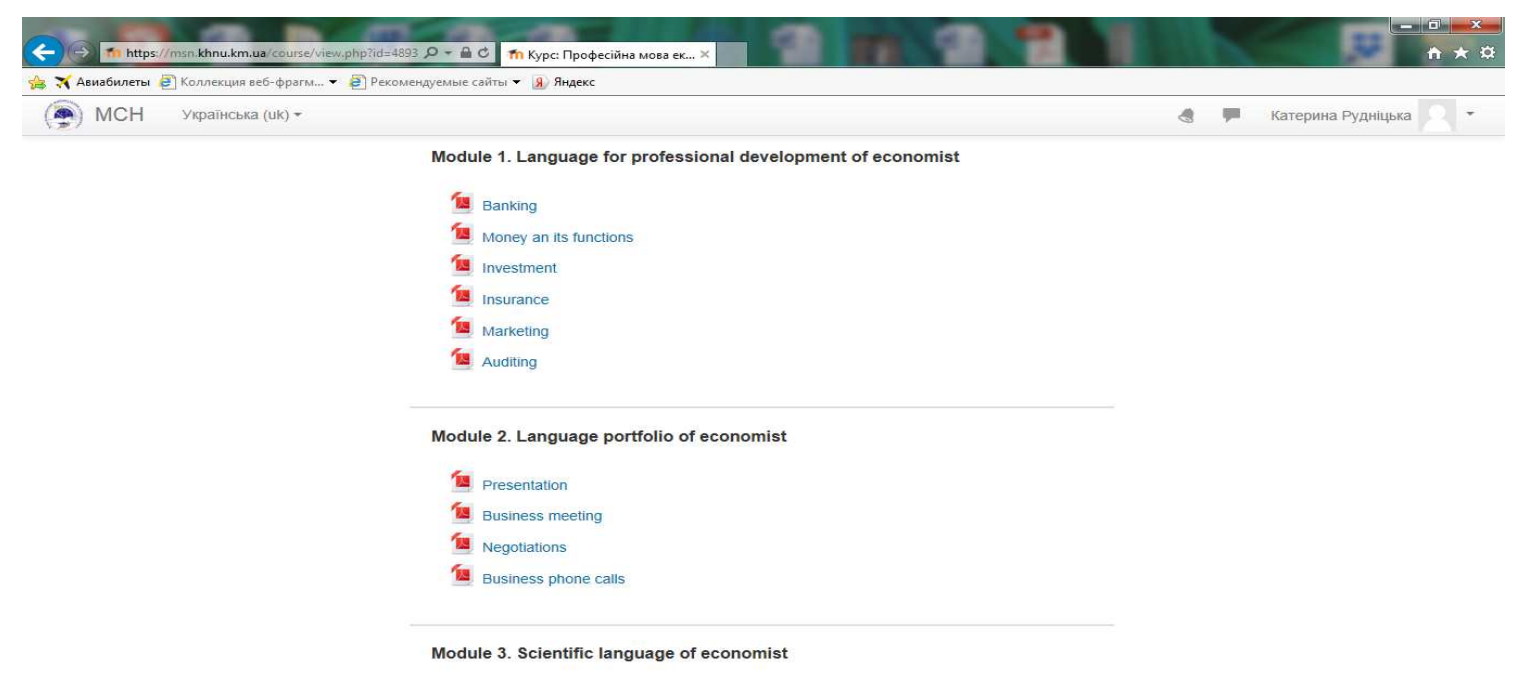

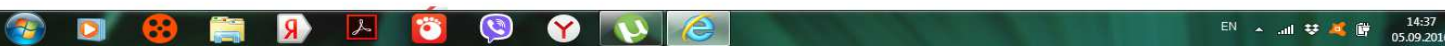

Рис. 2. Скріншот сторінки спецкурсу «Професійна мова економіста». Змістові модулі 
Робота над кожною темою передбачає засвоєння нового лексичного матеріалу i виконання тренувальних лексичних вправ, опрацювання основного тексту, післятекстових завдань для перевірки розуміння його змісту, реферативний переклад науково-технічного тексту. Вивчення теми завершується виконанням творчого завдання, відповідно до якого студенти мають підготувати доповідь, діалог або презентацію.

Блок завдань для самостійної роботи студента пропонує вивчення тем культурологічного, побутового характеру та містить:

- лексичні одиниці активного запасу;

- традиційні тренувальні вправи для засвоєння лексики активного словника, укладені на основі текстів;

- мовленнєві вправи, що стимулюють вільне спілкування;

- тестові завдання на закріплення тематичного матеріалу;

- комунікативні вправи, завдання та тести на розуміння прочитаного;

- проблемні ситуації для обговорення й розвитку навичок письма;

- питання для обговорення подій, дійових осіб, проблематики теми.

Наприклад, працюючи над темами «Student's daily routine», «Student's life», «Our university», студент має можливість осмислити себе в контексті свого студентського життя, поміркувати над проблемами взаємовідносин у групі, колективі, характером відносин, що складаються між одногрупниками, та основними детермінантами, що визначають їхній рівень. Зазначені теми стимулюють активність студента до самостійної роботи, надаючи їй ракурсу зацікавленого пошуку відповідей на важливі питання, а не механічного виконання стандартизованих завдань [4].

Виконання завдань для самостійної роботи передбачає використання інтерактивних технологій (дискусія, написання есе), ігрових (діалогові й рольові ігри), проектних технологій (проектування індивідуальної стратегії розвитку).

У такий спосіб актуалізуються й навчальні компетенції (потреби як основи мотивації навчальної діяльності, самоорганізації в процесі виконання завдання, рефлексивні вміння). Важливо ставити студентам запитання стосовно не лише результату виконання завдання, а й самого процесу. Наприклад, тема «Мій вихідний день» («Мy day off»):

- які джерела інформації з теми використовувалися, яким був процес їх пошуку?;

- визначте найбільші труднощі процесу й обгрунтуйте їх сутність;

- якими прийомами користувалися під час виконання навчального завдання, i наскільки вважаєте вдалим їх вибір (щоб ви змінили в процесі організації діяльності при повторному виконанні аналогічного завдання?);

- за рахунок яких слів поповнився ваш словниковий запас після опрацювання теми, які фразеологізми засвоїли?;

- що було найскладнішим під час виконання навчального завдання, які граматичні форми довелося повторити?;

- що б Ви порадили студентам врахувати надалі в опрацюванні нового матеріалу?

Домінанта в такому виді роботи - за самостійним пошуком. Цінністю $є$ те, що в центрі уваги студента - власне дозвілля, відпочинок, своя модель вихідного дня. Студент аналізує себе в контексті життєвого простору, здійснює свої проекти, виходячи з життєвих цінностей, аналізує свій вихідний день, зіставляючи його 3 іншими, представленими студентами на занятті. Якщо предметом обговорення стають актуальні життєві, особистісні проблеми і ситуації, то в студентів складається враження, що вони більше зосереджені на основному предметі спілкування, розмірковуючи над проблемами, захоплюючись самим процесом пошуку оптимального проекту організації власного 
відпочинку, що, своєю чергою, зумовлює: ставлення до мови як до інструмента пошуку істини, формування життєво важливих цінностей; свободи мовлення, пошуку адекватних варіантів вербального вираження своїх думок, аргументів, переконань; мотиваційної основи для самостійного подальшого вдосконалення мовної практики (словникового запасу, граматичної основи, побудови речень, фразеологізмів та ін.). Попри це, активно використовується мовний матеріал, що стосується концепцій i конкретних зразків організації відпочинку в контексті інших культур, інших національних особливостей, зокрема це стосується англомовних країн [5].

Однією 3 переваг авторського спецкурсу «Професійна мова економіста» $\epsilon$ можливість керування СРС (розподіл на групи, встановлення часових обмежень, варіювання кількістю спроб для виконання завдань, внесення необхідних коректив у процесі навчання) та здійснення контролю, самоконтролю за допомогою опитувань, контрольних робіт, тестів.

Фрагмент опитування з теми «HIGHER EDUCATION».

Talk about these questions:

1. What do you like and dislike in your student's life?

2. Why did you make up your mind to choose this major?

3. What are the advantages and disadvantages to leave home at the age of 17-18?

4. How do British universities differ from universities in our country?

5. What are the problems facing first-year students? Do Ukrainian and British students have the same problems?

Фрагмент контрольної роботи з теми «HIGHER EDUCATION».

Read the text. Choose true or false for the following statements. OXBRIDGE

Oxford and Cambridge universities are the oldest and most prestigious in Great Britain. They are often called collectively Oxbridge.

The degree course lasts 3 years, after which the students get the degree of Bachelor of Arts. Some courses such as languages or medicine may be one or two years longer. The students may study for other degrees as well. The degrees are awarded at public ceremonies. Oxford and Cambridge keep their traditions, such as the use of Latin at degree ceremonies.

Oxford and Cambridge universities consist of a number of colleges. Each college is different, but in many ways they are alike. Each college has its name, its coat of arms. Within a college there is a dining hall, a library, a chapel, rooms for undergraduates and fellows.

Oxford is one of the oldest universities in Britain, after London. There are now 24 colleges for men, 5 for women and other five for both men and women, many of them are overseas students.

Cambridge University started in the 13 th century. The oldest college is Peterhouse which was founded in 1284. The University was only for men until 1871, when the first women's college was opened. In the 1970s most colleges opened their doors to both men and women.

Many great men studied at Cambridge, among them Erasmus, the great Dutch scholar, Roger Bacon, the philosopher, Newton, the great scientist, and Kapitza, the famous Russian physicist.

The universities have over a hundred societies and clubs. Sport is part of students' life at Oxbridge. The most popular sport is rowing. 
(From "UK. Britain in Brief") Arts.

1. The degree course lasts 4 years, after which the students get the degree of Bachelor of

2. Oxford and Cambridge use English at degree ceremonies.

3. Each college has its name, its coat of arms.

4. London is one of the oldest universities in Britain, after Oxford.

5. Cambridge University opened its doors to both men and women.

Фрагмент тесту з теми «HIGHER EDUCATION».

Choose the correct word in each sentence:

1. Jack decided to take a course/lessons in hotel management.

2. Anna always gets good marks/grands in economics.

3. After leaving school, he studied/trained as a teacher.

4. Nick failed/missed his Math exam and had to sit it again.

5. The presence at the lecture, conference is monitoring/attendance.

На нашу думку, найбільш доцільним для перевірки набутих знань з іноземної мови протягом опанування спецкурсу є тестовий метод контролю, оскільки його використання забезпечує частоту контролю; уможливлює диференціювати й індивідуалізувати контроль; сприяє швидкому «зворотньому зв'язку». Як стверджує І. Морев, проходячи тест, студент може сам критично оцінити успіхи та невдачі у вивченні матеріалу та правильно організувати подальшу роботу, забезпечити ії системність та систематичність [6].

На формувальному етапі (2016-2017 рр.) експерименту впроваджено створений нами авторський спецкурс «Професійна мова економіста» й експериментально перевірено ефективність організації самостійної роботи студентів засобами Moodle. У ЕГ організація навчального процесу здійснювалася як цілісна система за умов упровадження авторського спецкурсу «Професійна мова економіста» й активного застосування Moodle. У КГ - за традиційною методикою.

Порівняння результатів стартового і підсумкового контролів у КГ та ЕГ довело ефективність організації самостійної роботи студентів засобами Moodle в процесі вивчення іноземної мови (рис. 3,4 ).

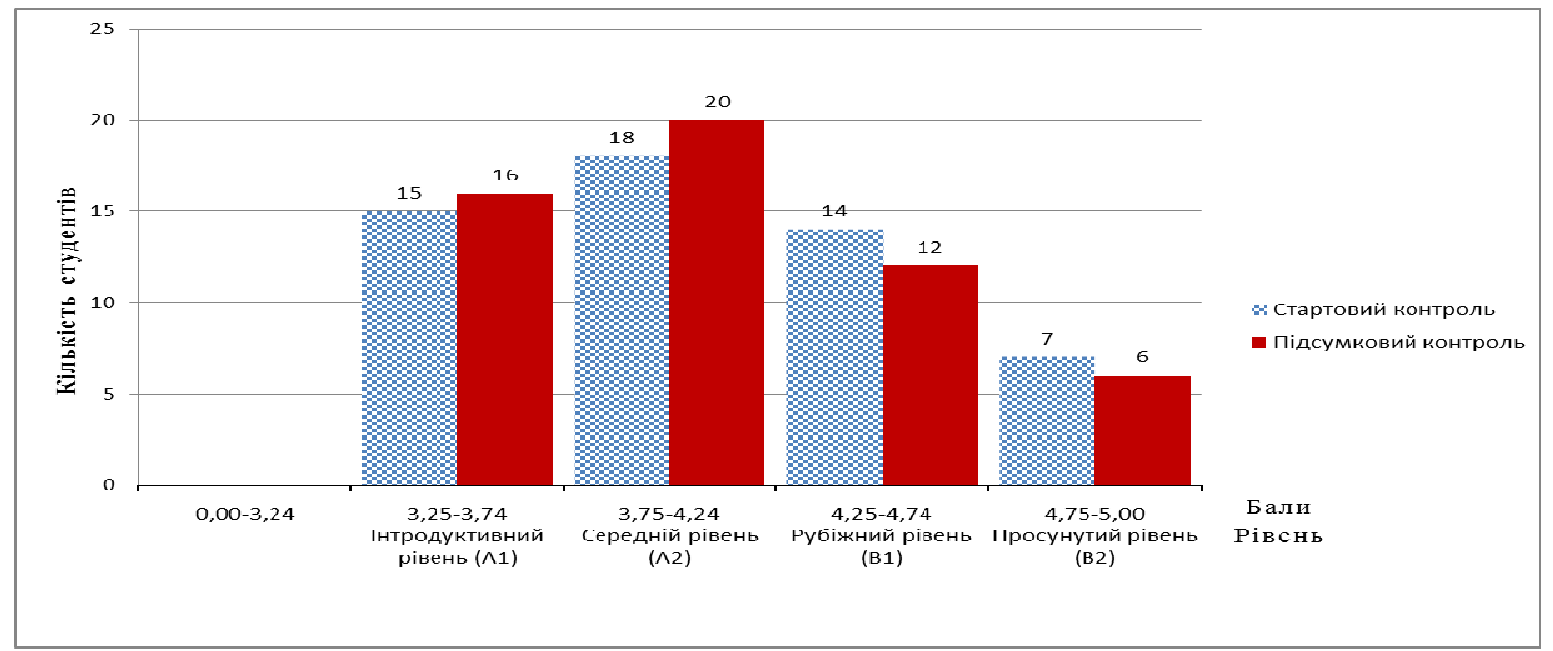

Рис. 3. Результати тестування контрольної групи 


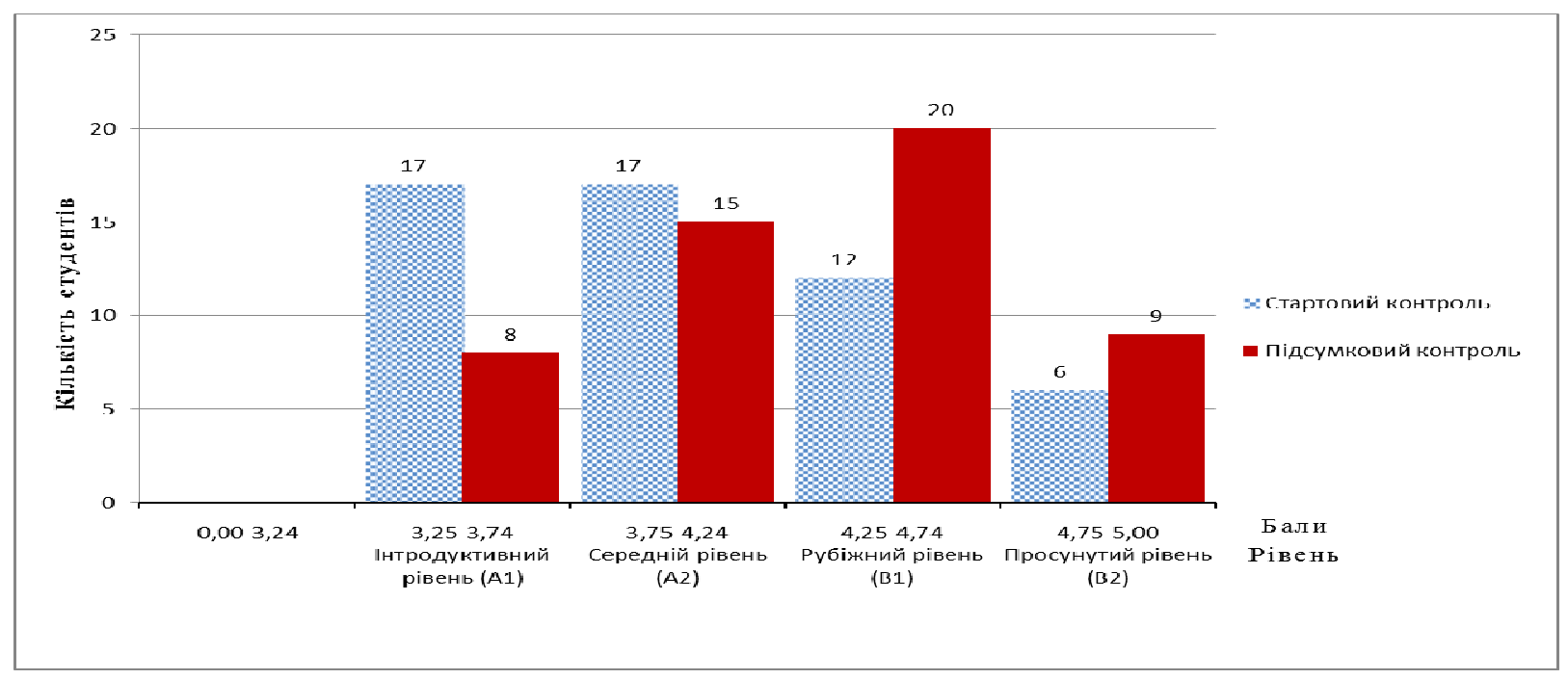

Рис. 4. Результати тестування експериментальної групи

Результати дослідно-експериментальної роботи, що були оброблені за допомогою методів математичної статистики, засвідчили такі зміни: кількість студентів ЕГ, які досягли найвищого - просунутого рівня володіння іноземною мовою, збільшилася на $5,77 \%$ (від 11,54\% до 17,31\%), а в КГ зменшилася на 1,85\% (від 12,96\% до 11,11\%). Кількість студентів, які мають рубіжний рівень в ЕГ збільшилася на 15,38\% (від 23,08\% до $38,46 \%$ ), у КГ - зменшилася на 3,71\% (від 25,93\% до 22,22\%). Зменшилися показники середнього рівня в ЕГ - на 3,84\% (від 32,69\% до 28,85\%), у КГ показники збільшилися на $3,71 \%$ (від 33,33\% до 37,04\%). Суттєво зменшилася кількість студентів, які мають найнижчий - інтродуктивний рівень: у ЕГ кількість студентів зменшилася на 17,31\% (від 32,69 до 15,38\%), а в КГ збільшилася на 1,85\% (від 27,78 до 29,63\%) (табл. 2).

Таблиця 2

Рівень володіння іноземною мовою студентами до і після експерименту

\begin{tabular}{|l|l|l|l|l|l|l|l|l|}
\hline \multirow{2}{*}{$\begin{array}{c}\text { Рівень володіння } \\
\text { іноземною мовою }\end{array}$} & \multicolumn{3}{|c|}{$\begin{array}{l}\text { До експерименту } \\
\text { Крупальна } \\
\text { (54 студ.) }\end{array}$} & $\begin{array}{l}\text { Експеримен- } \\
\text { тальна група } \\
\text { (52 студ.) }\end{array}$ & $\begin{array}{l}\text { Контрольна } \\
\text { група } \\
\text { (54 студ.) }\end{array}$ & $\begin{array}{l}\text { Після експерименту } \\
\text { Експеримен- } \\
\text { тальна група } \\
\text { (52 студ.) }\end{array}$ \\
\cline { 2 - 10 } & К-ть & $\%$ & К-ть & $\%$ & К-ть & $\%$ & К-ть & $\%$ \\
\hline Просунутий (В2) & 7 & 12,96 & 6 & 11,54 & 6 & 11,11 & 9 & 17,31 \\
\hline Рубіжний (В1) & 14 & 25,93 & 12 & 23,08 & 12 & 22,22 & 20 & 38.46 \\
\hline Середній (А2) & 18 & 33,33 & 17 & 32,69 & 20 & 37,04 & 15 & 28,85 \\
\hline Інтродуктивний (А1) & 15 & 27,78 & 17 & 32,69 & 16 & 29,63 & 8 & 15,38 \\
\hline
\end{tabular}

На узагальнюючому етапі (2017 р.) експерименту здійснено комплексний аналіз матеріалів експериментального дослідження, сформульовано висновки. 


\section{4. ВИСНОВКИ ТА ПЕРСПЕКТИВИ ПОДАЛЬШИХ ДОСЛІДЖЕНЬ}

Маємо зазначити, що розгляду питання організації самостійної роботи студентів у вищій школі завжди приділялась значна увага з боку науковців. У зв'язку з нормативним збільшенням iii обсягу виникла нагальна потреба у пошуках нових форм і методів організації СРС і вдосконаленні ії змісту, що сприятиме якісній підготовці кваліфікованих фахівців, здатних до саморозвитку, самоосвіти та самовдосконалення в умовах конкурентного ринку праці. У нашому дослідженні ми розглядали організацію СРС засобами Moodle в процесі вивчення іноземної мови.

Розроблено робочу програму й авторський спецкурс «Професійна мова економіста» засобами Moodle для вивчення іноземної мови студентами 1 курсу напрямів підготовки «Фінанси і кредит», «Економічна кібернетика», «Економіка підприємства», «Облік і аудит», який має чітку структуру. Визначено оптимальне коло тем для вивчення іноземної мови, які складають зміст СРС. Обгрунтовано, що для самостійної роботи доречно пропонувати студентам теми культурологічного і побутового характеру.

Створений авторський спецкурс «Професійна мова економіста» має низку переваг: можливість керування СРС і здійснення контролю, самоконтролю (ретельно обмірковані опитування, контрольні роботи та тести, які надають вичерпну інформацію про навчальнопізнавальну діяльність студента). Усі дії учасників детально протоколюються засобами Moodle.

Експериментально перевірено ефективність організації самостійної роботи студентів засобами Moodle в процесі вивчення іноземної мови після впровадження авторського спецкурсу «Професійна мова економіста». За результатами формувального етапу експерименту кількість студентів експериментальної групи, які досягли просунутого (В2) та рубіжного (В1) рівня володіння іноземною мовою, збільшилася відповідно на 5,77\% та $15,38 \%$ (у контрольній групі зменшилася відповідно на $1,85 \%$ та 3,71\%). Суттєво змінилися показники середнього (А2) та інтродуктивного (А1) рівня: в експериментальній групі кількість студентів зменшилася відповідно на $3,84 \%$ та $17,31 \%$, у контрольній групі збільшилася відповідно на $3,71 \%$ та 1,85\%. Результати дослідно-експериментальної роботи підтвердили ефективність організації самостійної роботи студентів засобами Moodle в процесі вивчення іноземної мови.

Перспективу подальших наукових розвідок убачаємо в дослідженні ефективності організації СРС засобами Інтернет-технологій і виокремленні особливостей організації СРС у ВНЗ країн Свропейського Союзу.

\section{СПИСОК ВИКОРИСТАНИХ ДЖЕРЕЛ}

[1] Верховна Рада України, (2014, Лип. 01). Закон № 1556-VII, Закон України «Про вищу освіту». [Електронний ресурс]. Режим доступу: http://zakon4.rada.gov.ua/laws/show/155618/page?text=\%E2\%E5.

[2] Л. М. Журавська, Методичні рекомендаиї̈ з організаиії самостійної роботи студентів. Ірпінь: УФЕІ, 1997.

[3] Moodle.org: open-source community-based tools for learning [Електронний ресурс]. Режим доступу: http://www.moodle.org.

[4] C. Kramsch, The Challenge of Globalization for the Teaching of Foreign Languages and Cultures, Electronic Journal of Foreign Language Teaching, vol. 11. nо. 2, pp. 249-254, 2014. [Електронний ресурс]. Режим доступу: http://eflt.nus.edu.sg/v11n22014/kramsch.pdf 
[5] К. В. Рудніцька, “Формування професійної мовної компетентності майбутніх фахівців економічного профілю у вищих навчальних закладах”, дис. канд. пед. наук, Нац. академія Держ. прикорд. служби України ім. Б. Хмельницького, Хмельницький, 2015.

[6] И. А. Морев, Образовательньге информационные технологии. Владивосток: изд-во ДГУ, 2004.

Матеріал надійшов до редакиії 13.11.2017 p.

\title{
ОРГАНИЗАЦИЯ САМОСТОЯТЕЛЬНОЙ РАБОТЫ СТУДЕНТОВ ПОСРЕДСТВОМ ИНСТРУМЕНТОВ МООDLЕ В ПРОЦЕССЕ ОБУЧЕНИЯ ИНОСТРАННОМУ ЯЗЫКУ
}

\author{
Рудницкая Екатерина Валериевна \\ кандидат педагогических наук, доцент кафедры иностранных языков \\ Хмельницкий национальный университет, г. Хмельницкий, Украина \\ ORCID ID 0000-0002-9644-8226 \\ karudik29@gmail.com
}

Дроздова Вероника Вячеславовна

кандидат педагогических наук, доцент, доцент кафедры иностранных языков

Хмельницкий национальный университет, г. Хмельницкий, Украина

ORCID ID 0000-0002-2367-8784

ehorova@ukr.net

\begin{abstract}
Аннотация. Авторы проанализировали проблему организации самостоятельной работы студентов в высшей школе на основе изучения педагогической, психологической и методической литературы, программно-методической документации ВУЗов, опыта практической работы. В связи с нормативным увеличением почасовой нагрузки на самостоятельную работу студентов возникла необходимость использования Moodle. Выявлено, что организация самостоятельной работы студентов посредством инструментов Moodle в процессе изучения иностранного языка недостаточно исследована. Для решения указанной проблемы разработана новая рабочая программа по изучению иностранного языка студентами экономических специальностей первого года обучения и авторский спецкурс «Профессиональная речь экономиста». Определены основные преимущества спецкурса для организации самостоятельной работы студентов, мониторинга и анализа активности студентов в процессе изучения иностранного языка. Экспериментально проверена и доказана эффективность организации самостоятельной работы студентов посредством инструментов Moodle в процессе изучения иностранного языка.
\end{abstract}

Ключевые слова: самообразование; самостоятельная работа студентов; Moodle; иностранный язык; учебно-познавательная деятельность; авторский спецкурс; контроль.

\section{ORGANIZATION OF STUDENTS' SELF-STUDY BY MEANS OF MOODLE SYSTEM FOR FOREIGN LANGUAGE LEARNING}

\section{Kateryna V. Rudnitska}

PhD (in Pedagogical Sciences), Associate Professor of the Foreign Languages Department

Khmelnytsky National University, Khmelnytsky, Ukraine

ORCID ID 0000-0002-9644-8226

karudik29@gmail.com

Veronika V. Drozdova

PhD (in Pedagogical Sciences), Associate Professor, Associate Professor of the Foreign Languages Department Khmelnytsky National University, Khmelnytsky, Ukraine

ORCID ID 0000-0002-2367-8784

ehorova@ukr.net 


\begin{abstract}
The authors have analyzed the problem of students' self-study organization at higher school on the basis of studying pedagogical, psychological and methodical literature, program-methodical documentation of higher educational institutions, experience of practical work. In accordance with the normative increase on students' self-study load, there was a need to use Moodle system. It has been found out that the organization of students' self-study by means of Moodle system in the process of foreign language learning has not been properly researched. To solve this problem, a new curriculum and the author's special course «Professional language of an economist» for foreign language learning have been developed and implemented for the first-year students of economic specialties. The main advantages of the special course for organization of students' self-study, monitoring and analysis of students' activity in the process of foreign language learning have been determined. The effectiveness of organization of students' self-study by means of Moodle system in the process of foreign language learning has been experimentally tested and proved.
\end{abstract}

Key words: self-education; students' self-study; Moodle system; foreign language; educational and cognitive activity; author's special course; control.

\title{
REFERENCES (TRANSLATED AND TRANSLITERATED)
}

[1] Verkhovna Rada of Ukraine (2014, Jul 01). Law No. 1556-VII, Law of Ukraine "On Higher Education". [online]. Available: http://zakon4.rada.gov.ua/laws/show/155618/page?text=\%E2\%E5. (in Ukrainian)

[2] L. Zhuravska, Guidelines on the Organization of Independent Study of Students. Kyiv: Irpin: UFEI, 1997. (in Ukrainian)

[3] Moodle.org: open-source community-based tools for learning [online]. Available: http://www.moodle.org (in English).

[4] C. Kramsch, The Challenge of Globalization for the Teaching of Foreign Languages and Cultures, Electronic Journal of Foreign Language Teaching, vol. 11, no. 2, pp. 249-254, 2014. [online]. Available: http://eflt.nus.edu.sg/v11n22014/kramsch.pdf (in English)

[5] 4. K. Rudnitska, "Formation of Professional Language Competency of Future Economists in Higher Education Institutions", PhD thesis, the National Academy of State Border Guard Service of Ukraine named after Bohdan Khmelnytsky, Khmelnytsky, 2015. (in Ukrainian)

[6] Morev, Educational Information Technologies. Vladivostok: izd-vo DGU, 2004. (in Russian)

\section{(cc) BY-NC-SA}

This work is licensed under Creative Commons Attribution-NonCommercial-ShareAlike 4.0 International License. 